\title{
LETTERS OF THE KING Djed kare-Isesi
}

\author{
By \\ Mohamed Refaat
}

demonstrator at tour guidance department

Faculty of Tourism \&Hotels. Suez Canal University

\section{Dr. Samar Mosleh}

Dr. of Egyptology

Faculty of Tourism \&Hotels. Suez

Canal University
Prof. Mofida El-Weshahy

Prof. of Egyptology

Faculty of Tourism \&Hotels.

Suez Canal University

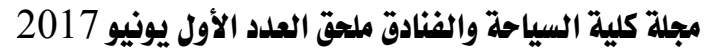

الخاص بالمؤتثر العلمي الأول السياحة و الاثار - الفرص و التحدي التديات 


\section{LETTERS OF THE KING DJED KARE-ISESI}

\section{Mohamed Refaat ${ }^{1}$ Dr. Samar Mosleh ${ }^{2}$ Prof. Mofida El-Weshahy ${ }^{3}$}

Djedkare-Isesi, the 8th ruler of the fifth dynasty, appears to make various expeditions, trade relations and activities outside the Egyptian valley of the Nile so that letters and official messages were sent for many reasons. Some letters were written during the era of the king Djedkare-Isesi , two of these letters was for Senedjemib the most powerful man at Isesi's court here narrates his favors with the king, one of which his majesty wrote with his own hand. A lake of 1,200 cubits' length is planned for by the architect, and the king expresses his delight with the plan. The closing inscriptions were the work of Senezemib's son, who after his father's death recorded in the tomb the mortuary endowment of his father and the presentation of the sarcophagus by the king. One of these letters was for Rashepses the chief justice and vizier, the overseer of scribes of royal documents.

The Research aims to shed light on the letters of King, to identify the circumstances that led to the sending these letters and for whom were sent.

\section{Introduction}

Isesi was the Eighth ruler of the Fifth dynasty, 4 Succeeded after the King Menkauhor,5 He ruled for more than thirty years (r.2436-2404 BCE).6 The Turin Canon documents told us that he ruled for about 28 years, but Manetho suggests that it lasted for about forty years.7

It seems that the era of that king was an era full of great works. 8 The reign of Djedkare saw important changes in the sphere of religion and mortuary cult.9 The king began a conservative policy towards the doctrine of the sun in the city of Heliopolis without departing from it entirely.10

Under his long reign the administration expanded. The provincial officials gained greater autonomy from the central administration to redress the balance, the office of the "overseer of upper Egypt" answering directly to the central administration. ${ }^{11}$

King has sent some letters between him and his ministers and the documents told us that the number of these letters was three letters. 12 The epistologic sources of the old kingdom were divided into three groups based 
on the sender and recipient, which are defined as "king's briefs", "officials and privet briefs" as well as "briefs to dead" 13

The royal letters will be discussed below always have a royal sender and receivers, who are always high in the state administration.14 These letters are recorded in hieroglyphics script and the bearer is stone. 15

These letters are translated and analyzed with regard to their structure, location and context with other inscriptions of the tomb, then the phraseological structure is to be dealt and corrected.16

\section{$A$ first letter from the king Dd $k A$ Ra- Isesi to snDm-jb-Giza Mastaba of Senedjemib (Fig. 1)17}

Date: Fifth dynasty at the second half of the reign of the Djed kare-Isesi.

Provenance: the north side corner of the west cemetery of Giza

Material: Sandstone

Present location: facade of the mastaba of snDm -ib (Giza G 2730) (pl.1)18

Sender: $\underline{d} d-k 3-R^{e}$ Isesi

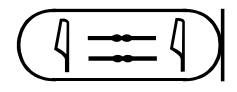

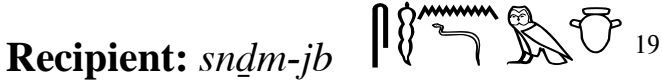

\section{Description}

The inscriptions were found at the Tomb of, Chief Judge Vizier, And Chief Architect,20 snDm -ib (Giza G 2730) is located on the north side corner of the west cemetery of Giza and are listed at PM III.1 85 ff. (plan XXVI). The tomb was dated with Baer in the second half of the reign of the Djed kare Isesi.21

He was the most powerful man at Isesi's court here narrates his favors with the king, in the course of which he includes verbatim two letters from his lord,22 one of which his majesty wrote with his own hand. A lake of 1,200 cubits' length is planned for by the architect, and the king expresses his delight with the plan. Unfortunately, the fragmentary state of the inscription renders the narrative very obscure.23(fig.2-3) 24

The closing inscriptions were the work of senedjemib's son, who after his father death recorded in the tomb the mortuary endowment of his father, and the presentation of the sarcophagus by the king. 25

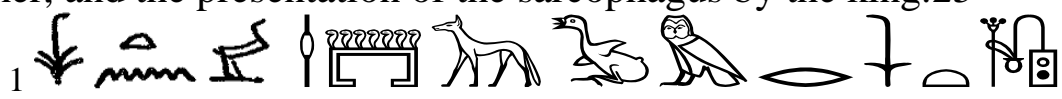


Letters of the King Djed kare-Isesi

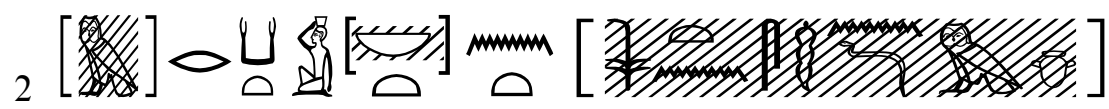

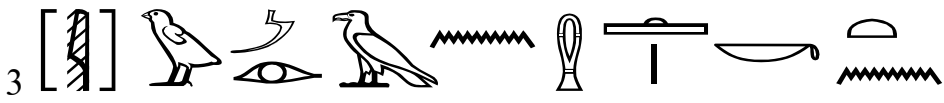

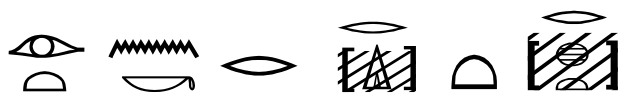

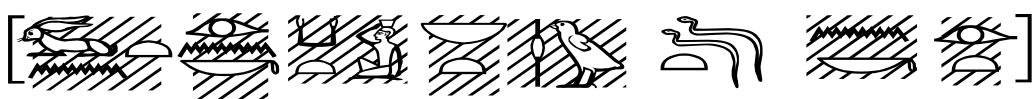

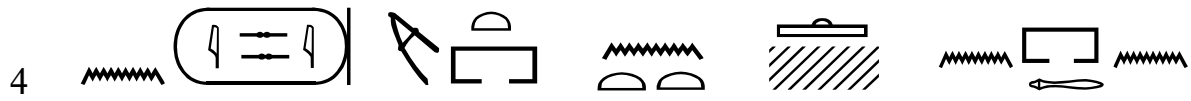

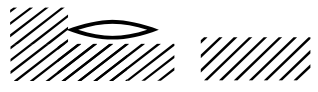

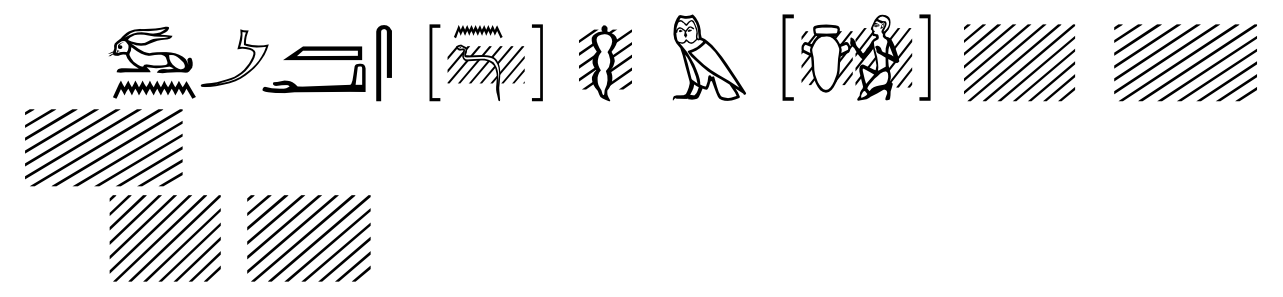

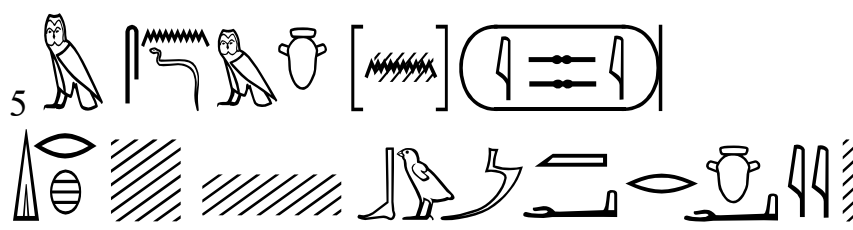

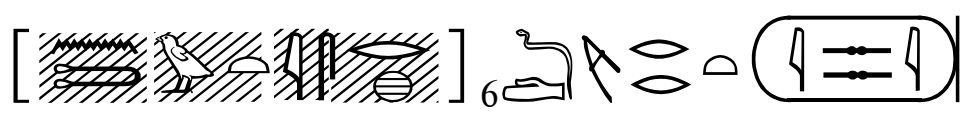

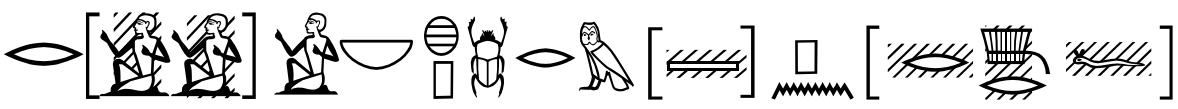

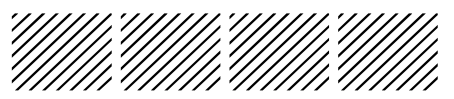

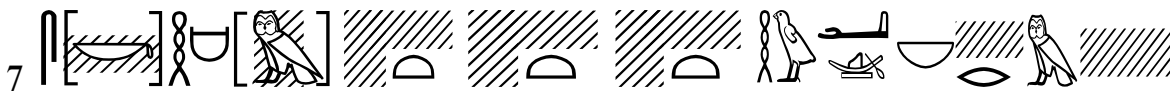



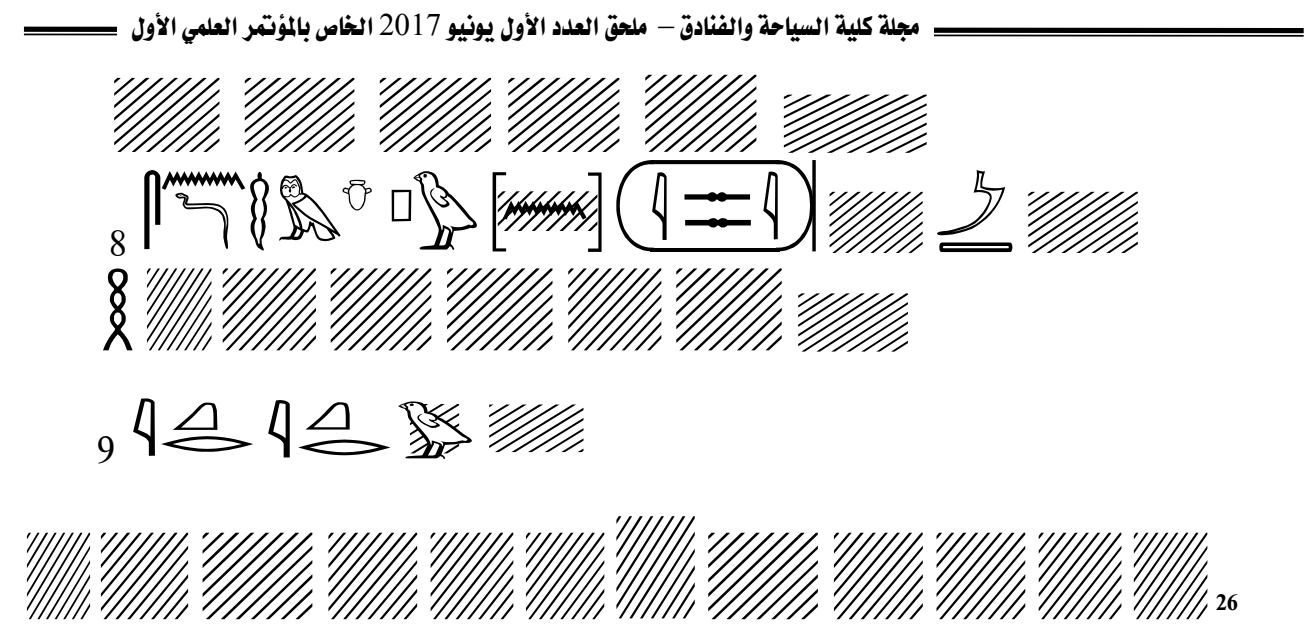

\section{Transcription}

(1) wd nswt t3ty z3b t3ty imy-r\} zšw ‘n nswt (2) imy-r\} $k 3 t$ [nb] th $\{t$ nswt

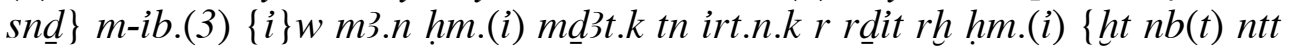

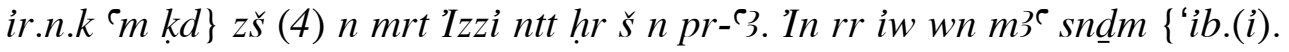

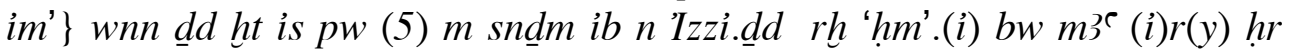
' $\{w\}(y)$. \{ in hm\} wn r hpr twt (6) dd mrrt 'Izzílr\} s'h nb hpr m 't\}' pn. $\{r[h] . n .(i) \underline{t}\} w[t \breve{s p s}]$ wrt n.(i) $\{m\}$ (i) šst, (7) $\{s k\}$ hm h̆m.(i) rh.(i) wnt hִ ${ }^{\top} w$ $n b$ 'hr nfrw'. $\{f\} . t[w] t n$. (I) dd imy-r\}' ' $k 3 t$ nbt n' $(t) n s w t$. (8) sndm ib pw n 'Izzi 'm3't' m3't. h'j' $i\{w\}$ [t.k\} hr.(i) [n] 'irr'.k ht pw hr.'s' (9) ikr ikr \{i\}w ir. $\{n . k$ $h h w\} n w$ zp $\{m r \underline{t} w\}[h m . i]\{s k h\}$ m rh.t(i) $m r r$. (i) tow 27

\section{Translation and commentary}

(1) Royal decree to the chief justice and vizier, overseer of scribes of royal records, (2) and overseer o $\{\mathrm{f}\}[\mathrm{al}] 1$ works o\{f the king, Senedj $\}$ emib.

(3) My Majesty has seen this letter of yours which you wrote in order to inform My Majesty of \{everything that you have done in drafting the decoration (4) of the Hathor chapel of Isesi which is on the grounds of the palace. Can I have been correctly info \{rmed? Don't let\} it be said that it is a matter (5) of (just) gratifying Izezi! Let 'My Majesty' know the truth about it immediate $\{l y\}$ ! \{And if $\}$ it is $\{$ yet $\}$ to happen, you are (6) one who says what isesi likes \{better than\} any official who has (ever) come into being in this 'land.' (7) \{Inasmuch as\} My Majesty knows that every ship is 'on an even keel,' $\{\mathrm{I} \mathrm{kn}[\mathrm{ow}]$ in $\}$ what way $\{\mathrm{y}\}$ ou [are one who is] very [valuable] for me. The speaking of the overseer of all works of the king is 'pleasing' to me.1 (8) It is an informing of Isesi very correctly If only [you] could co]me to me, [since] you 'do' this (sort of) thing because of 'it' (9) in the best manner. You have performed innumerable deeds, (in such a way) that [My Majesty] should love you, and assuredly you know that I do love you.28 
A second letter from the king Dd-kA-Ra/ Isesi to snDm-jb- Giza Mastaba of Senedjemib (Fig. 4) 29

Date: Fifth dynasty at the second half of the reign of the Djed kare Isesi, dated to year 16 or 26 .

Provenance: the north side corner of the west cemetery of Giza

Material: Sandstone

Present location: North wall of portico of the mastaba of snDm -ib (Giza G 2730)(fig.6-5)30

Sender: $\underline{d} d-k 3-R$ \% Isesi $4=4$

Recipient: $s n d m-j b$ ?

\section{Description}
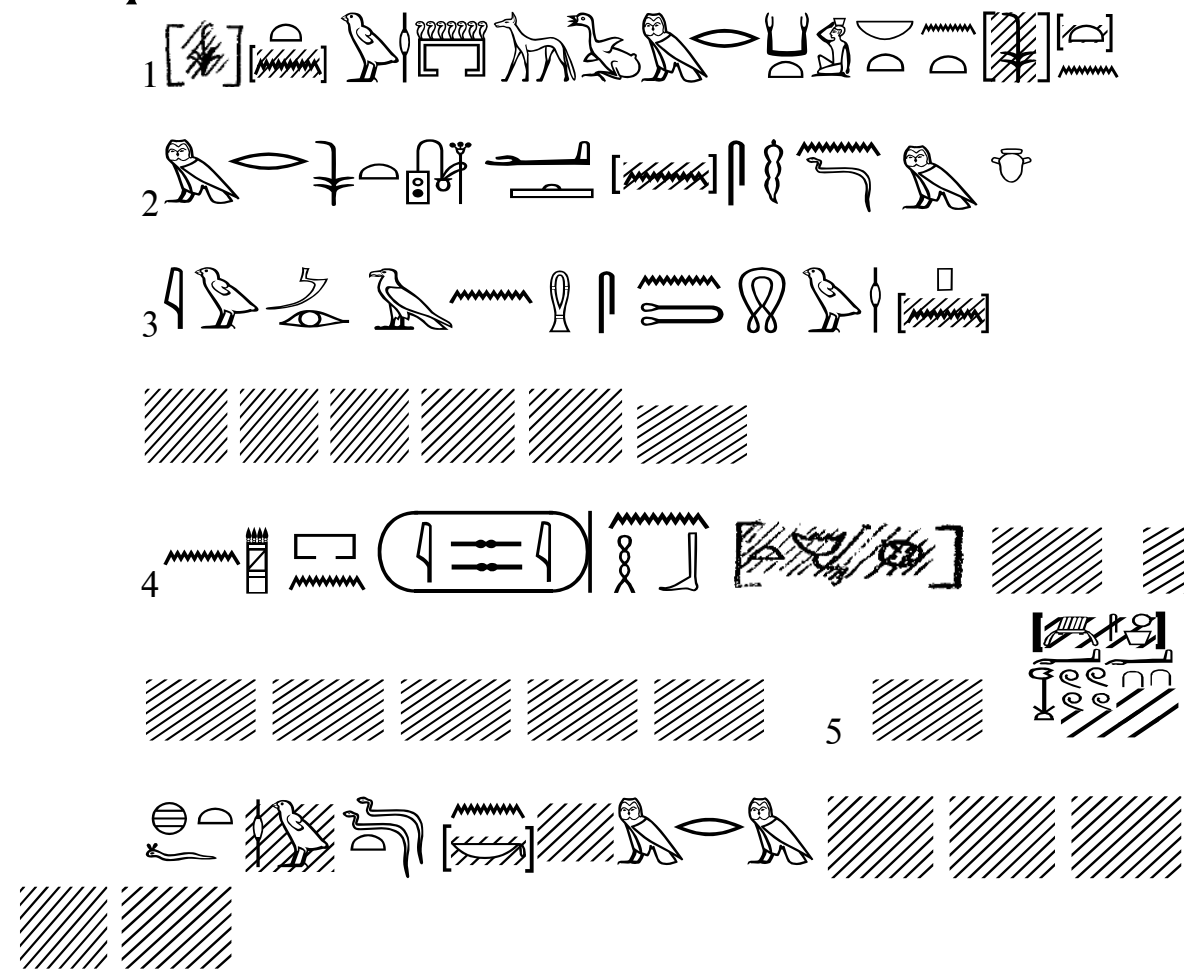

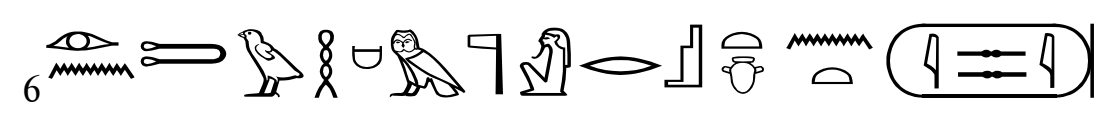




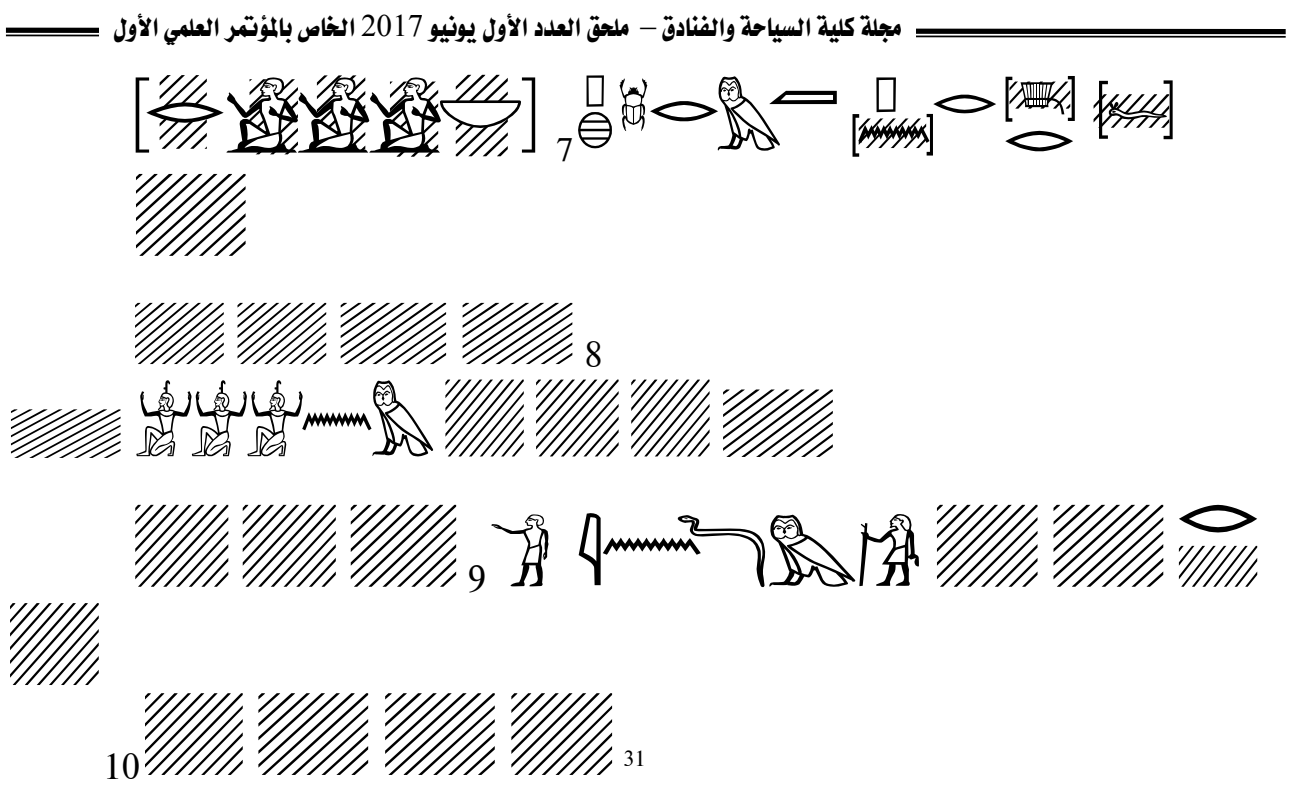

\section{Transcription}

(1) 'cw $\underline{d}$ nswt' t3ty z3b 't3ty' imy-r3 k3t nbt nt[swt\} (2) imy-r\} zšw ` $n$ $n s w t$ sndm-ib [wr\}. (3) iw m3.n hm.(i) sntw pn \{rdi.n.k[in]. $\{t(i) . f\} r$ sij $m$ stp-z3 $n$ š $n$ 'sht' (4) n 'nḥ n 'Izzi $n$ ḥb-'sd' sk $\{\underline{t w}\}$ 'dd. K' hr ḥm.(i) wnt ir.n.k $\{s\} w\{r\}(5)^{\prime} 3 w$ ' mh $1000\{r\}$ [shw] mh '440' hft wd d 10 t n.k m stp-z\}. Rh wi $\{\underline{t}\} w\{t r\} \underline{d d}$ mrrt $\{i z z i r h t n b\}$ (6) ir.n tw hrm ntr r st-ib nt Izzi iw hm. (i) hmw. ' $k$ ' $r$ imy-r3 k3t nb(t) (7) hpr $m$ t3 pn $r$ [d] r.f. iw (i) hr.kwrt ir. [t(i)] ' $m r$ ' [t] $r$ ht $n b(t)$. iw hm ir.n.k (8)'hrp' hhw nw [zp]. \{iw.[k] rirt imy\}-r\} k3t nt $n s w t$ (9) $i\{\check{s}\}$ ndm-ib wr $\operatorname{mr}\{r\}$.(i) tw h hm sk ḥm rh.t(i) mrr.(i) (10) rnpt-zp['] '6’ 3bd 4 šmw sw 2832

\section{Translation and commentary}

(1)'Royal decree' (to) the chief justice and 'vizier,' overseer of all works of the $\mathrm{k}$ [ing], (2) and the overseer of scribes of royal documents Senedjemib [the Elder].

(3) My Majesty has reviewed this ground plan \{which you [se]nt to be considered at court for the (pool?) precinct of the broad court (4) belonging to the 'jubilee' palace of "Lotus-of- Isesi." Now you say into My Majesty that you have made $\{i\} t$ (5) to 'a length' of 1,000 cubits (523 meters) and \{to $\}$ [a width] of ' 440 ' cubits (230 meters), in accordance with what was commanded to you in the court council. How well \{indeed y\}ou know how to say \{better than anything \} what \{Isesi \} wishes. (6) It is surely in accordance with the heart's desire of Isesi that god has made you. 
'My Majesty knows' that 'you' are more skillful than any overseer of works (7) who has (ever) come into being in this [en]tire land. Much has been done through you so that what I want more than anything might [be] done. You have indeed acted as (8) 'director' on innumerable [occasions]. And [you] \{are (henceforth) to serve as overseer of all works of the king. (9) $\mathrm{O}\{\mathrm{Se}\}$ nedjemib the Elder, I assuredly lo\{ve $\}$ you, and assuredly it is known that I love you, (10) Year of [I] ' 6 ' the count, 4th month of the third season, day 28.33

\section{A third letter from the king Dd-kA-Ra/ Isesi to Spss-Ra - Sakkara $\begin{array}{ll}\text { Mastaba of Shepses Ra (Fig. 7) } 34 & \end{array}$}

Date: Fifth dynasty at the reign of the Djed kare Isesi

Provenance: Saqqara

Material: Sandstone

Present location: At the back entrance of mastaba of Shepses Ra (pl.2)35

Sender: $d d-k 3-R$ / Isesi

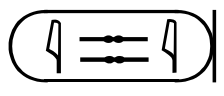

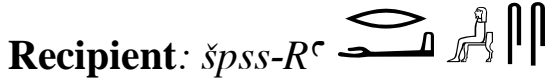

\section{Description}

The letter is located at the rear entrance of mastaba of Rashepses which was firstly excavated by Quibell PM III, 496 at Saqqara.36 The letter includes a horizontally written letterhead and vertical columns with the text of the letter, which consists of eleven columns and one line. We can see letterhead wD niswt, which in turn follows the title and then the name of the official. The columns are left from right to left.37
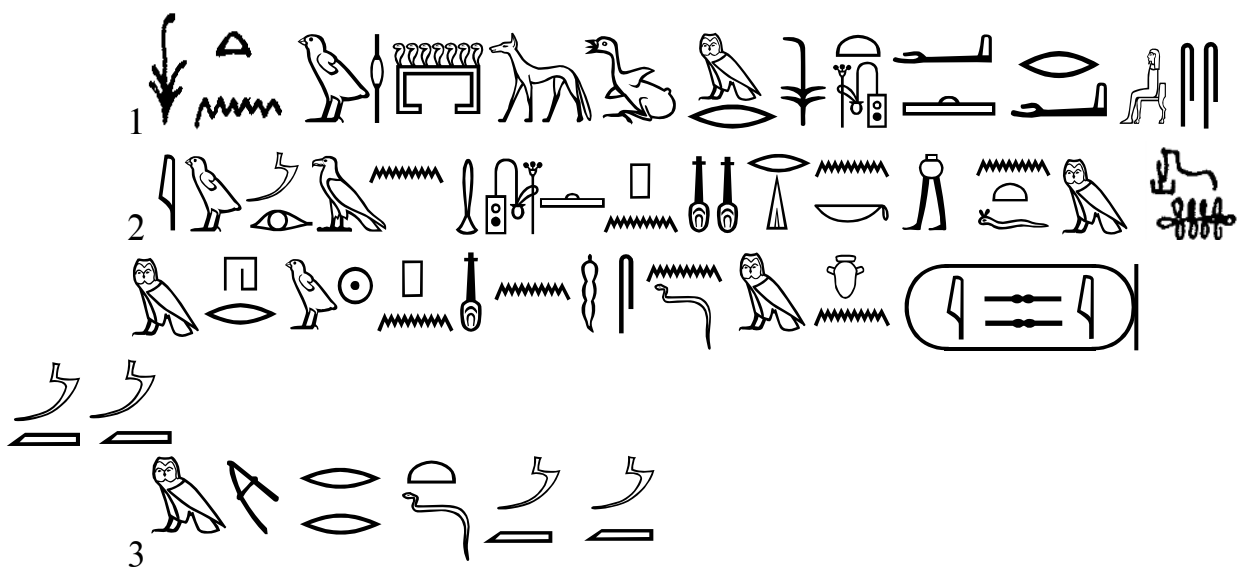


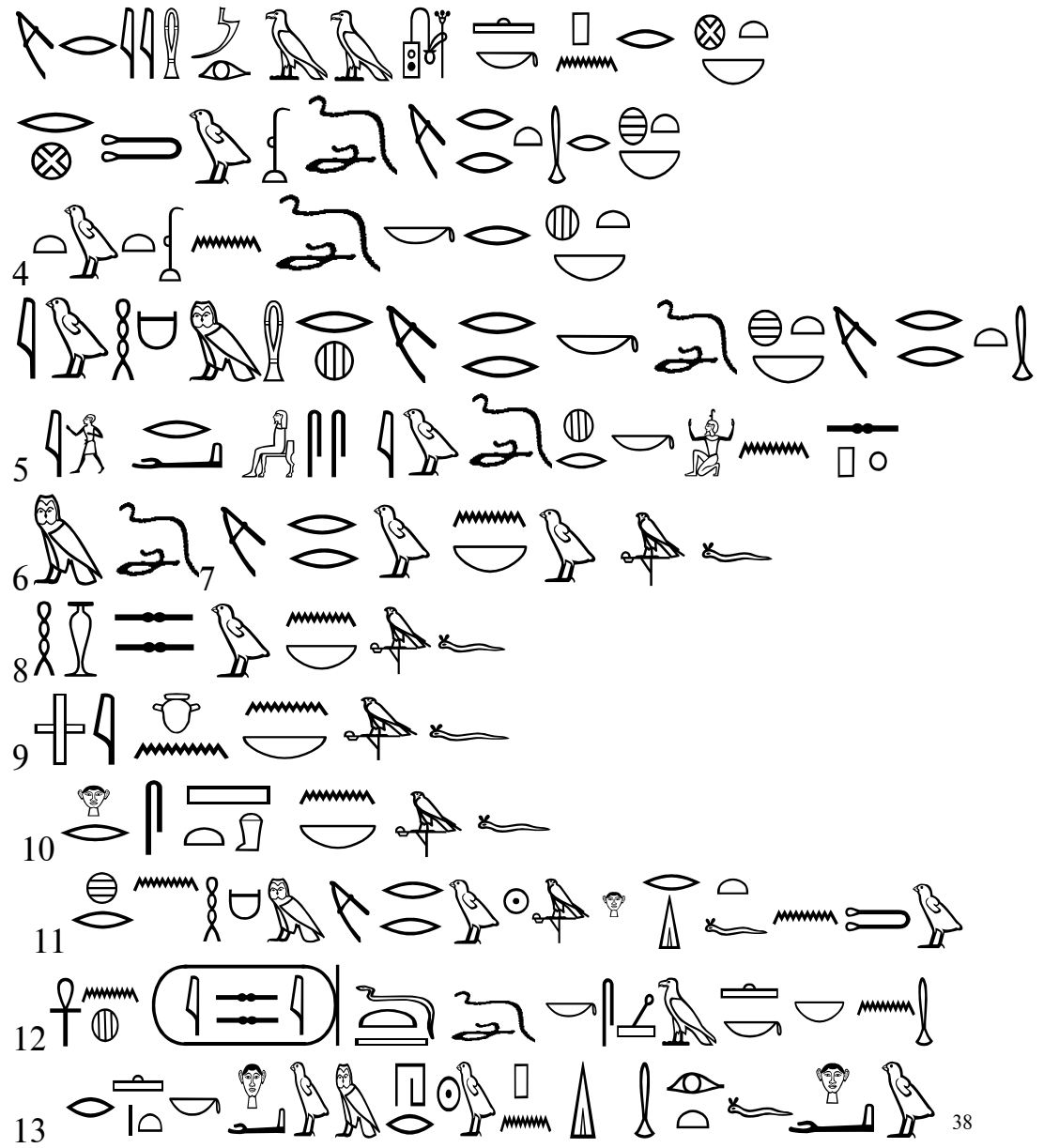

\section{Transcription}

(1)' 'wd nswt' t3ty z3b 't3ty' imy-r3 zšw 'n nswt špss r' (2) iw m3.n hmm.(i) zšw pn nfrw di n.k in ntf $m$ stp s3 $m$ hrw pn nfr $n$ sndm ib n izzi mзry $m$ mry $\underline{d} t$

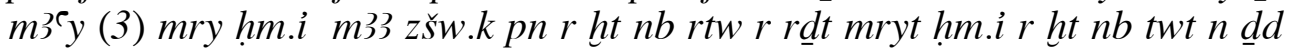
.k r ht nb (4) iw nhm hmm rh mry .k dd ht nb mryt hmm (5) i spss $r^{c} i w d d ~ h r . k$ $n$ sp (6) $m \underline{d} d$ mry $n b . f(8) h s w$ n.k nb.f (9) imy(w).n ib n.k nb.f (10) hr šst n.k $n b . f(11)$ hr $n$ nhmm mry rdit.f $n$ tww (12) ' $n h$ 'Izzi dt $\underline{d} d . k$ sš3.k nb.n hm. (f) (13) r..k hrr w $m$ hrw pn di ḥm(f) m33t.f $h r^{\top} w$.

\section{Translation and commentary}

(1) Royal decree to the chief justice and vizier, the overseer of scribes of royal documents, ShepsesRa:

(2)My Majesty has read at court this very fine letter that you sent on this fine day of very truly gratifying Isesi with what he very truly like. (3)It 
was more desirable to my majesty than anything else to read this letter of yours, for your surely know how to express what My Majesty likes above else, and your diction is surely more pleasing to me than anything else. (4)My Majesty knows full well that you desire to say everything that My Majesty like.

(5)Oh Shepses Ra, I say to you innumerable times as follows: (6) (7) O you who are beloved of your lord, (8) praised of your lord, (9)who are favorite of your lord (10) and who are privy to your lord's secrets, (11) it is because Re has given you to me that I know full well that he must love me. (12) As truly as Isesi lives forever, you should express immediately any wish of yours (13) in a letter from you today so that My Majesty might have it fulfilled immediately.39

\section{Conclusion}

- The main purpose of first letter is that the king respond to his minister snDm-jb after which he had done in drafting and decoration of the Hathor chapel of Isese.

- The first and the second sentences were always written horizontally and then completed the rest vertically. It is also noted that the sentence no.6 in the 3rd letter was written horizontally.

- The writer started the letter no.1\&2 with $\Downarrow_{\min }^{\Delta} \hat{\mathbb{H}} \oint$ w $d$ nswt reversing the real direction of the text to draw attention and highlights, it means a royal command.

- The overseer sndm-jb first and the second letters were noted the absence of that nickname unlike King $d d-k 3-R^{c}$, his birth name Isesi $4=4$ was the only one of his title to be mentioned in the first and the second letter.

- At the third letter, the repetition of the phrase $N b f$ which means of his lord to confirm the loyalty of špss-R` to the king $\underline{d} d-k 3-R^{\top} /$ Isesi

- At the end, it's important to highlight the tombs of the overseers and seniors of the old kingdom and make a tourism development to these tombs as it maintained precious documents 
Fig. (1):-

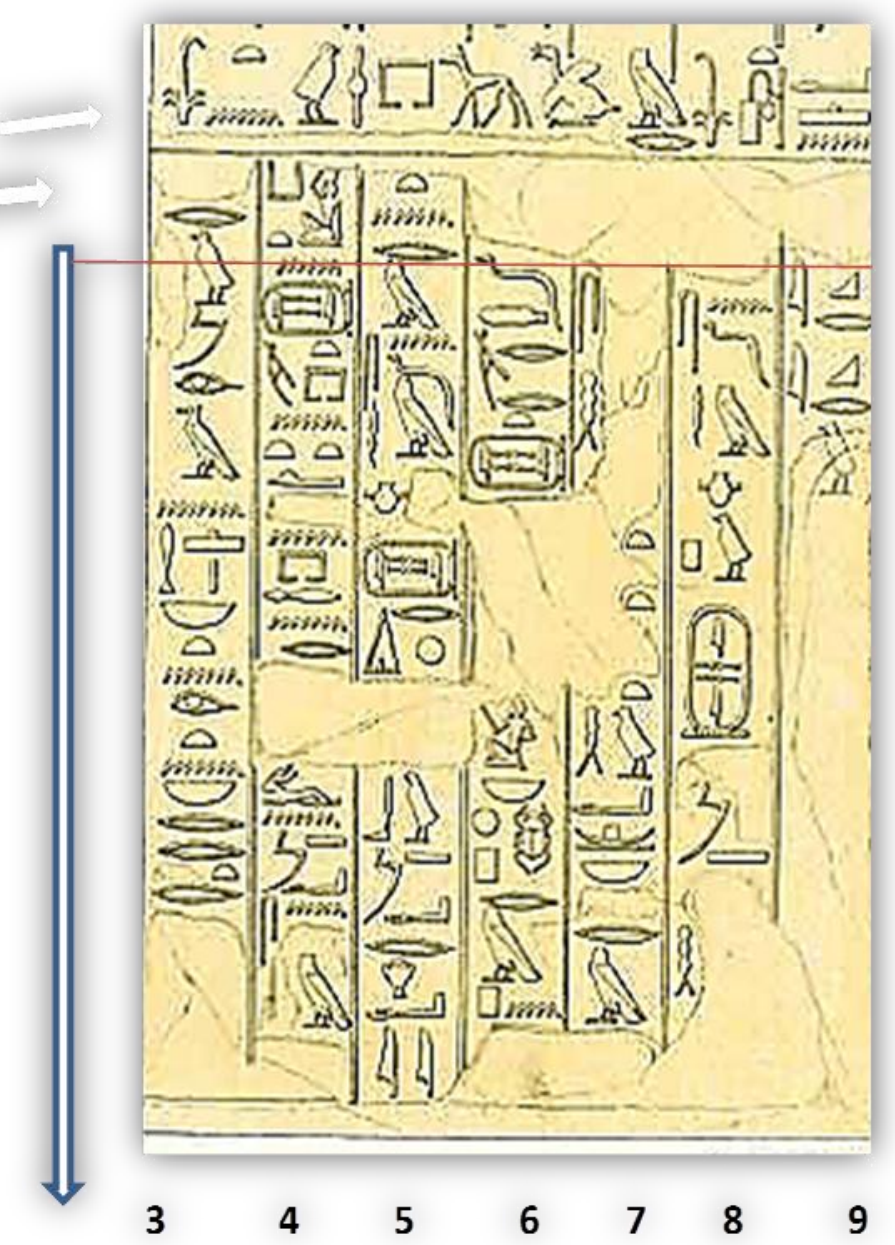

\section{A first letter from the king $\underline{d} d-k 3-R^{\top} w /$ Tsesi tq $s n \underline{d} m-j b / j n t j$ - Giza Mastaba of Senedjemib}

After: $L D$, pl. II, $76 \mathrm{~d}$ 
Fig. (2):-

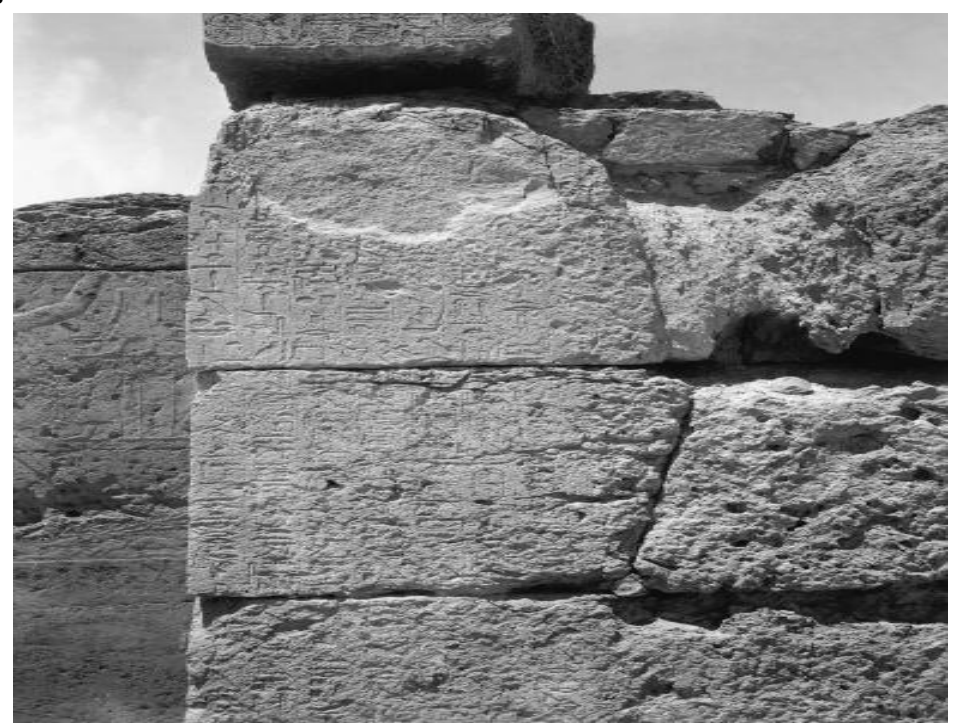

Senedjemib (G 2370), facade, north of portico, A first letter from the king $\underline{d} d-k 3-R^{\top} /$ Isesi to snDm-jb with end of Inscription at top. 3 August 1930. HU-BMFA Exp. Ph. a 5811

After: Edward Brovarski, The Senedjemib Complex, Part 1, Boston, 2001, pls. 58

Fig. (3):-

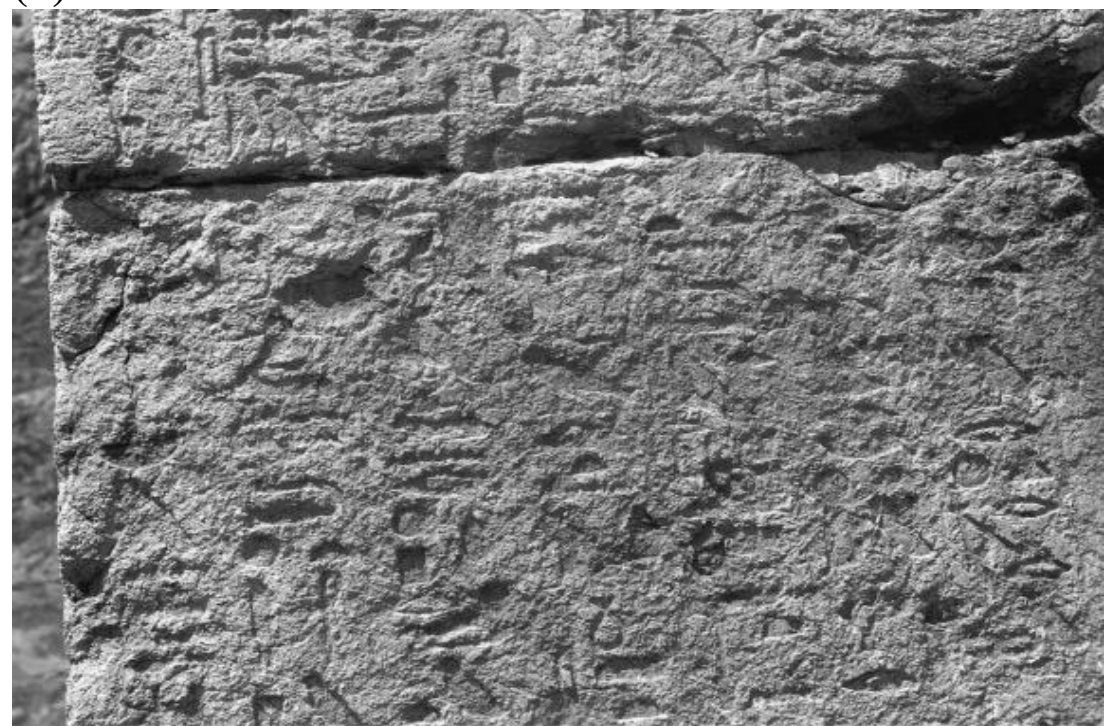

Senedjemib (g 2370), facade, north of portico, A first letter from the king $d d-k 3-R^{\top}$ / Isesi to snDm-jb , bottom. 9 September 1913. HU-BMFA Exp. Ph. a 1058

After: Edward Brovarski, The Senedjemib Complex, Part 1, Boston, 2001, pls. 63b 


\section{pl. (1):-}

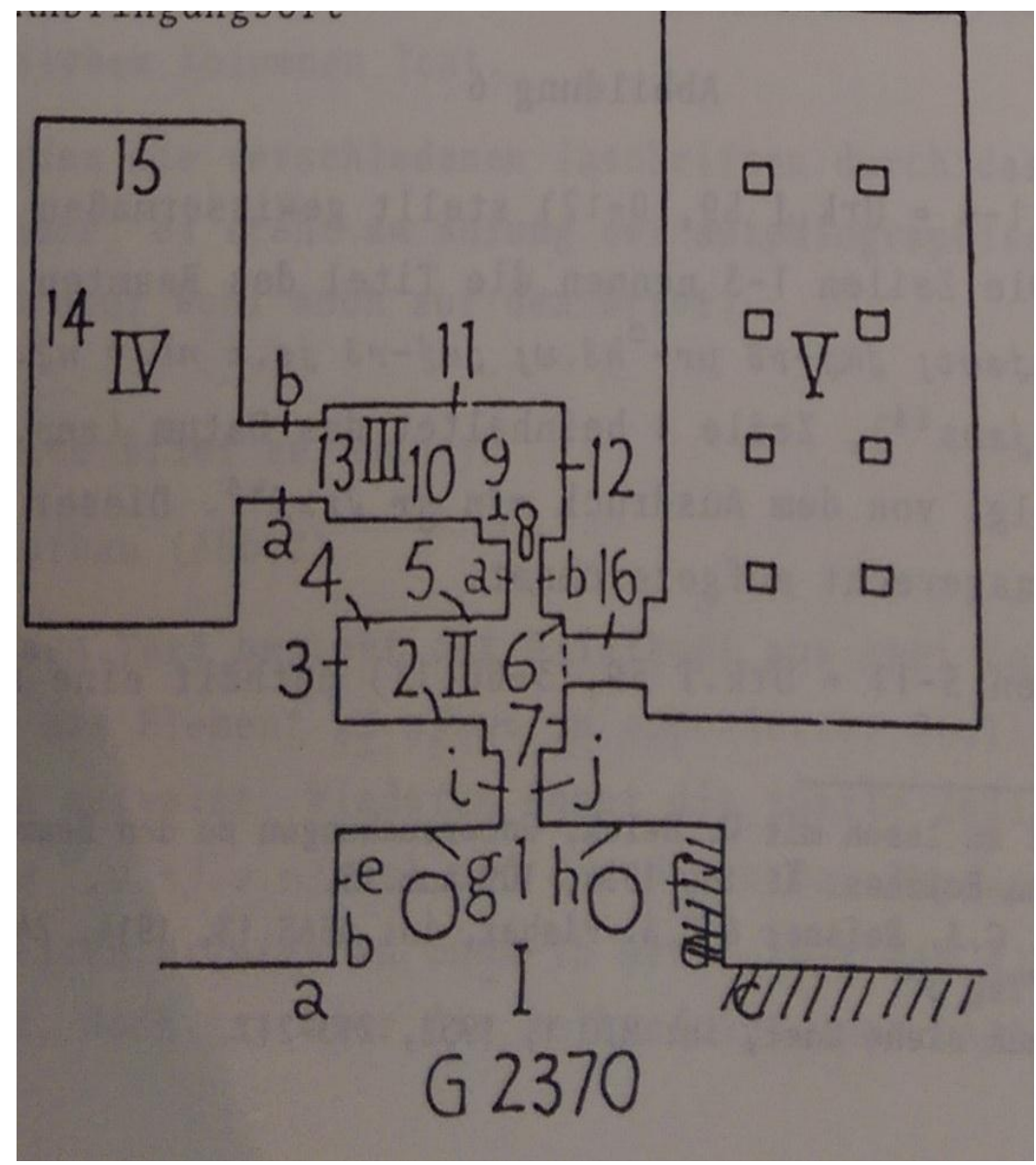

Mastaba of Senedjemib (G2370)

After: Eckhard Eichler, Untersuchungen zu den Königsbriefen des Alten Reiches, SAK, vol. 18, 1991, pp. 155 
Fig. (4):-

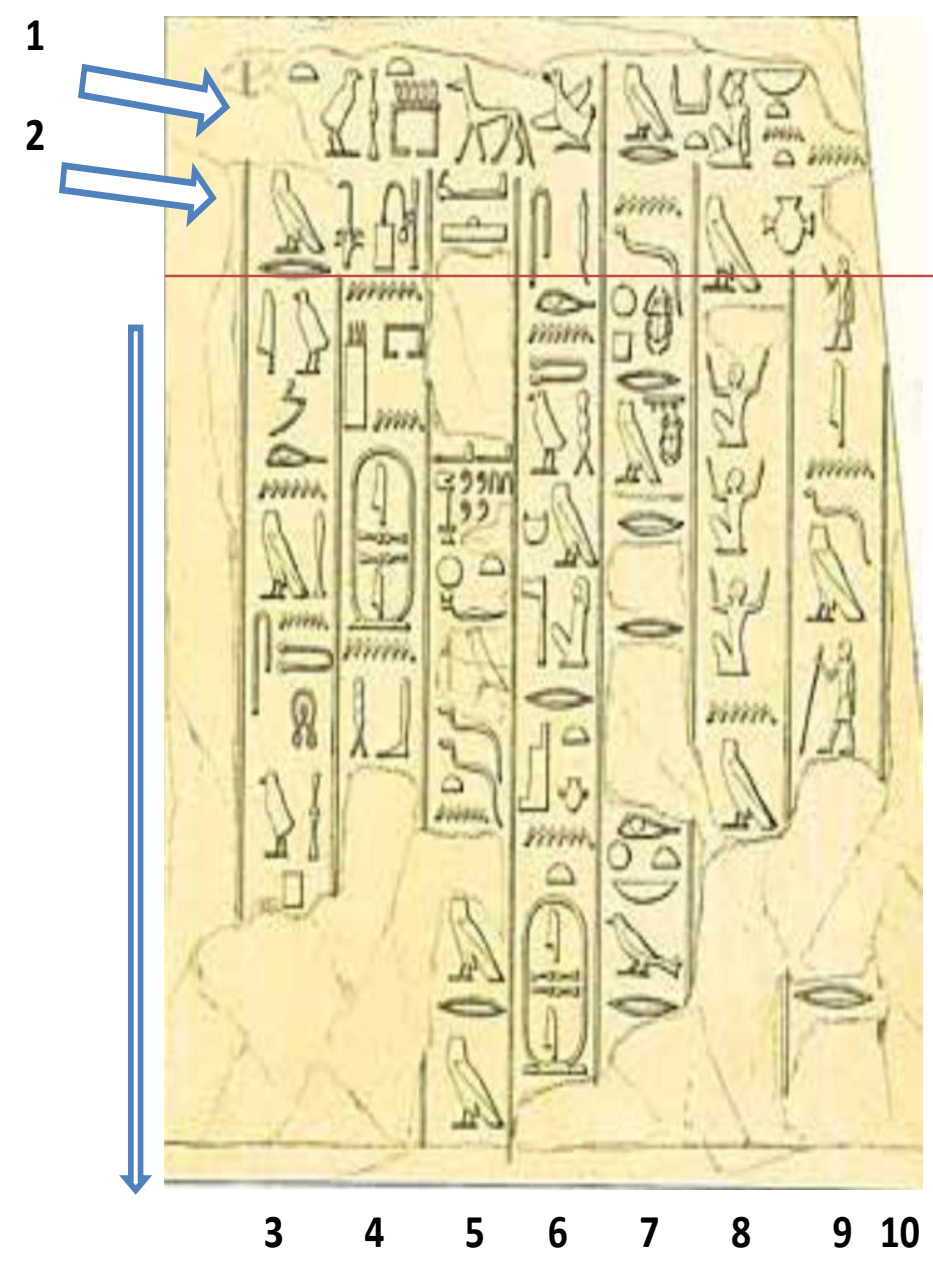

A second letter from the king $\underline{d} d-k 3-R$ \% Isesi to $s n \underline{d} m-j b$ - Giza Mastaba of Senedjemib

After: $L D$ II, pl. 76d 
Fig. (5):-

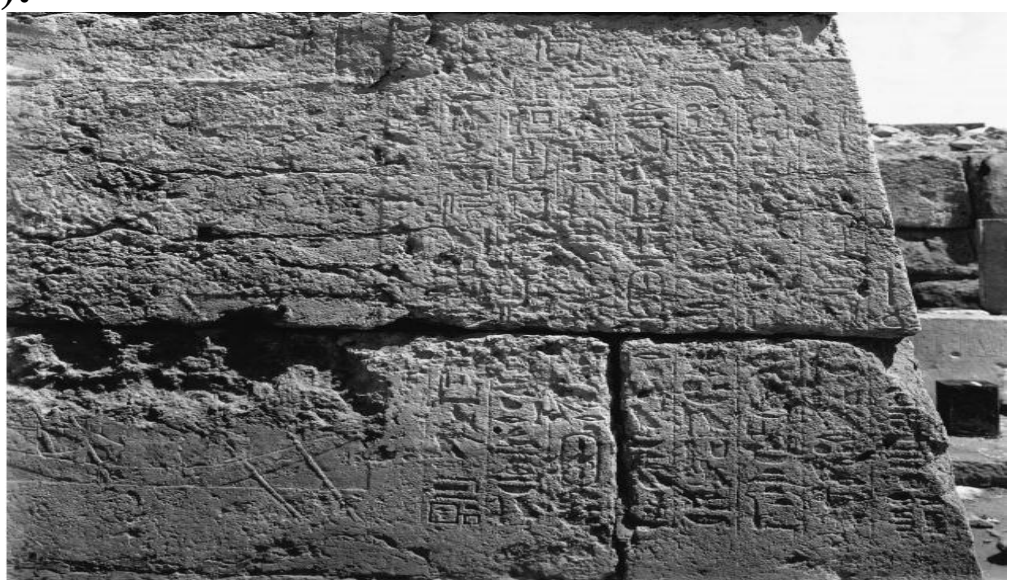

Senedjemib (G 2370), portico, north wall, A second letter from the king $\underline{d} d-k^{\complement}-R^{\top} /$ Isesi to $s n d m-j b$ at bottom. 4 August 1930. HU-BMFA Exp. Ph. a 5816

After: Edward Brovarski, The Senedjemib Complex, Part 1, Boston, 2001, pls. 65

Fig. (6):-

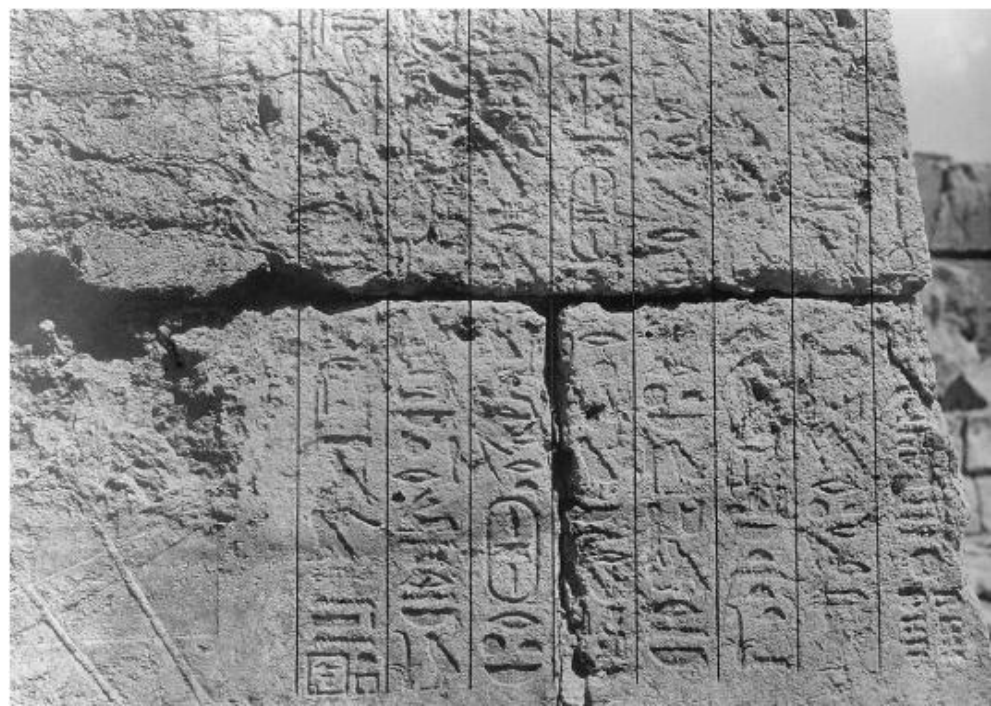

Senedjemib (G 2370), portico, north wall the second letter, with modern lines in ink. 26 February 1931. HU-BMFA Exp. Ph. a 6329

After: Edward Brovarski, The Senedjemib Complex, Part 1, Boston, 2001, pls. 66b 
Fig. (7):-

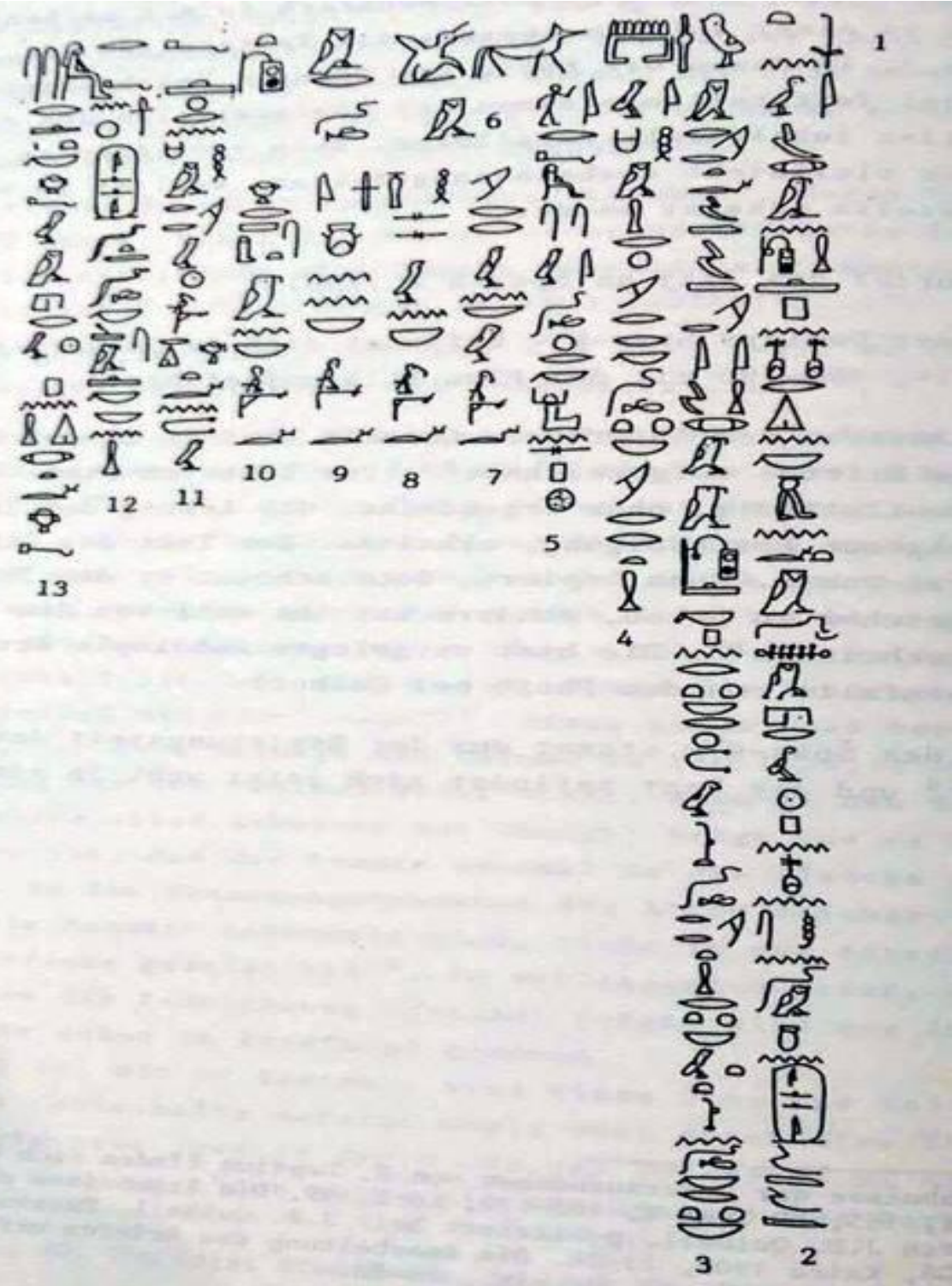

A third letter from the king $\underline{d} d-k 3-R^{\Upsilon} / 1$ sesi tq ${ }^{5} p s s-R^{\Upsilon}$ - Sakkara Mastaba of shepses $R^{r}$

After: Eckhard Eichler, Untersuchungen zu den Königsbriefen des Alten Reiches, SAK, vol. 18, 1991, pp. 150 


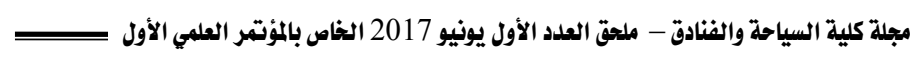

pl. (2):-

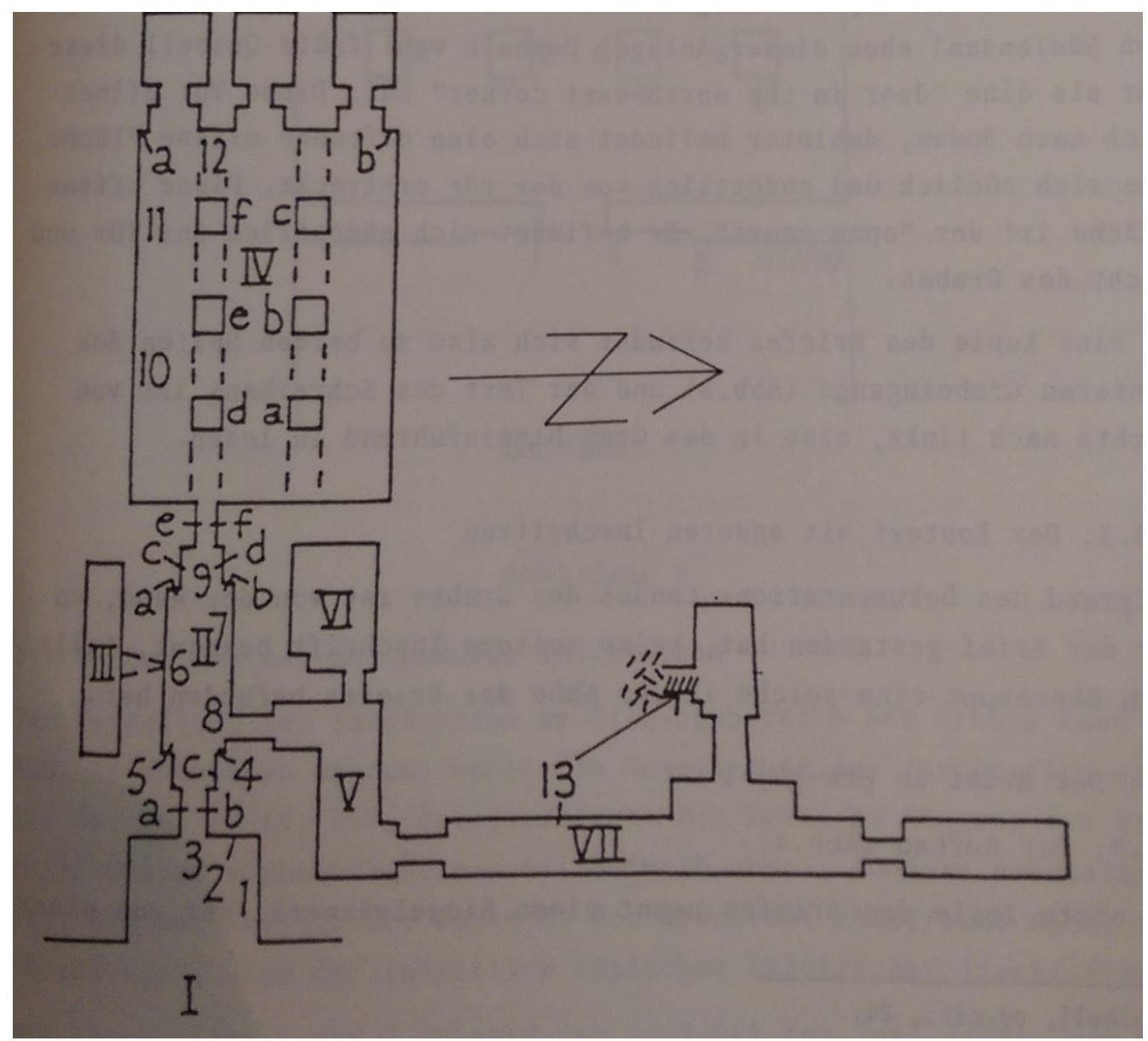

Mastaba of Shepsesa Ra L5 16 (5902)

After: Eckhard Eichler, Untersuchungen zu den Königsbriefen des Alten Reiches, SAK, vol. 18, 1991, p. 159 
${ }^{1}$ demonstrator at tour guidance department Faculty of Tourism \&Hotels. Suez Canal University

${ }^{2}$ Dr. of Egyptology Faculty of Tourism \&Hotels. Suez Canal University

3. Prof. of Egyptology Faculty of Tourism \&Hotels. Suez Canal University

${ }^{4}$ Margaret R. Bunson, Encyclopedia of Ancient Egypt, New York, 2001, p.186. 5ليم حسن ، موسوعة مصر القديمة: في مدنية مصر وتثافتها فى الدولة القديمة و العهد الأهناسى، ج2، القاهره،

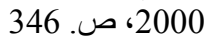

${ }^{6}$ Donald B. Redford, The Oxford Encyclopedia of Ancient Egypt, 2 vols, Oxford: USA university in Cairo press, 2001, p.600; M. lehner, the complete pyramids, Cairo: American university in Cairo press, 2004, p.149.

${ }^{7}$ N. Grimal, A history of ancient Egypt, trans. by Ian show, Cambridge USA: Blackwell press, 1992, p.79

${ }^{9}$ Donald B. Redford, op. cit., p.589.

$$
\text { . مليم حسن، المرجع السابق، ص. } 346 \text {. }
$$$$
\text { 10 عبد العزيز صالح، حضارة مصر القدبية وأثاره: في الاتجاهات الحضارية العامة حتي اواخر الألف الثالث ق.م، }
$$

${ }^{11}$ Donald B. Redford, op. cit., p.600.

${ }^{12}$ Edward Wente, Letters from Ancient Egypt, Atlanta, 1990, no. 4, p. 18.

${ }^{13}$ Eckhard Eichler, Untersuchungen zu den Königsbriefen des Alten Reiches, SAK, vol. 18,1991, p. 141.

${ }^{14}$ Breasted, Ancient Records of Egypt, vol. I, Chicago, 1906, section 268.

${ }^{15}$ Eckhard Eichler, op. cit., p. 142.

${ }^{16}$ Ibid., p. 142.

${ }^{17}$ LD II, pl.76d.

${ }^{18}$ Eckhard Eichler, op. cit., p. 155.

1937 sndm-jb means To make heart pleased; after: Wb. IV, 186.12-18.

${ }^{20}$ Breasted, op. cit., section 268

${ }^{21}$ Eckhard Eichler op. cit., p. 14.1

${ }^{22}$ Edward Brovarski, The Senedjemib Complex, Part 1, Boston, 2001, pp. 92-94.

${ }^{23}$ Breasted, op. cit., section 268.

${ }^{24}$ Edward Brovarski, op. cit., pls. 58,63b.

${ }^{25}$ Ibid., section 269.

${ }^{26}$ Urk. I, 60, 12 - 61,14; LD II,pl. 76d.

${ }^{27}$ James Henry Breasted, op. cit., section 271; Edward Wente, op. cit., no. 4, p. 19; Edward Brovarski, op. cit., pp. 92-94; Alessandro Roccati, La littérature historique sous l'Ancien Empire égyptien, Paris, 1982, § 93, p. 125.

* $\hat{\pi}$ zAb means judge, senior over, Housekeeper; after: Wb. IV, 421.7-422.2; Jones, Titles OK, no. 2932; Ward, Titles, no. 1263.

*qd; after: $W b$. VI, p. 73, 13-24; AEO 1, p. 71; FCD, p. 287 is meant in both cases. The

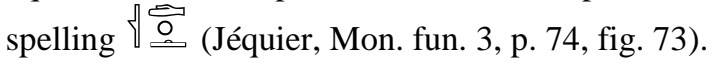


๑ zp times, occasions ; after: $W b$. III, 436.2-438.12.

${ }^{28}$ Edward Wente, op. cit., p. 19; Eckhard Eichler, op. cit., p. 144.

${ }^{29} \mathrm{LD}, \mathrm{pl}$. II, 76 f.

${ }^{30}$ Edward Brovarski, op. cit., pls. 65,66b.

* 8 According to $W b$. IV, p.179, 2-3, snt, "ground plan" is not attested before the middle kingdom.

* and Hb-sd according to Bissing-Kees, Re-Heiligtum 2, pl. 1 [1 a], Neuserre is depicted inspecting the building of the "keep" or "palace" constructed especially for the jubilee ceremonies.

* xrp means Supervisor, director; after: $W b$, III, 326.8-327.5; FCD, p. 196.

${ }^{31} \mathrm{LD}, \mathrm{II}, \mathrm{pl}$ 76f; Urk, I, 62,13-63,11.

${ }^{32}$ Edward Brovarski, op. cit., pp. 96-101; French translation by Alessandro Roccati, La littérature historique sous l'Ancien Empire égyptien, Paris, 1982, § 95, p. 126.

${ }^{33}$ James Henry Breasted, op. cit., section 273; Edward Wente, op. cit., pp. 18-19.

${ }^{34}$ Eckhard Eichler, op. cit., p. 150.

${ }^{35}$ Ibid., p. 159.

${ }^{36}$ PM III, 496.

${ }^{37}$ Eckhard Eichler, op. cit., p. 151.

${ }^{38}$ Urk. I, 179,8-180,10.

${ }^{39}$ Edward Wente, op.cit., no. 2, p.18; Alessandro Roccati, op.ci., § 58, pp. 78-79. 